\title{
Efektivitas Ekstrak Kulit Manggis Sebagai Terapi Adjuvan Terhadap Perbaikan Gejala dan Tanda Klinis serta Kualitas Hidup Pasien Rinitis Alergi
}

\section{Effectiveness of Mangosteen Skin Extracts As Adjuvant Treatment Against Improvement of Clinical Symptoms, Signs, and Quality of Life of Allergic Rhinitis Patients}

\author{
Oke Kadarullah $^{1}$, Lina Lasminingrum² ${ }^{2}$ Iwin Sumarman ${ }^{2}$ \\ ${ }^{1}$ Bagian Ilmu Kesehatan Telinga Hidung Tenggorok Bedah Kepala dan Leher \\ Fakultas Kedokteran Universitas Muhammadiyah Purwokerto \\ ${ }^{2}$ Departemen Ilmu Kesehatan Telinga Hidung Tenggorok Bedah Kepala dan Leher \\ Fakultas Kedokteran Universitas Padjadjaran/ Rumah Sakit Hasan Sadikin Bandung \\ Email: okadarullah@gmail.com, lina_tht@yahoo.com, iwinsumarman@yahoo.com
}

\begin{abstract}
Abstrak
Latar belakang: Rinitis alergi (RA) merupakan penyakit inflamasi di mukosa hidung yang diperantarai IgE setelah paparan alergen. Polusi dapat memperberat inflamasi alergi. Terapi RA ditujukan untuk memperbaiki gejala, mencegah perburukan, dan meningkatkan kualitas hidup. Ekstrak kulit manggis merupakan herbal yang lazim digunakan sebagai terapi adjuvan/tambahan dengan efek antiinflamasi dan antioksidan. Kapasitas antioksidannya lebih tinggi dibandingkan buah lain. Tujuan penelitian ini adalah untuk menilai perbaikan gejala klinis, tanda klinis, serta kualitas hidup pada RA menetap sedang berat.
\end{abstract}

Metode: Penelitian ini merupakan quasi experimental randomized trial open label pre and post test design. Penelitian berlangsung di poliklinik Ilmu Kesehatan Telinga Hidung Tenggorok Bedah Kepala Leher Rumah Sakit Dr. Hasan Sadikin Bandung bulan September-November 2013. Kelompok kontrol mendapat terapi standar berupa tablet loratadin dan kortikosteroid intranasal, sedangkan kelompok perlakuan diberi tambahan kapsul ekstrak kulit manggis selama 14 hari. Diagnosis berdasarkan anamnesis, pemeriksaan fisik dan tes kulit tusuk. Lalu dinilai skor gejala hidung semikuantitatif Weeke, Davis dan Okuda (TNSS), skor nasoendoskopi adaptasi Lund Kennedy, serta skor gangguan kualitas hidup RQLQ dari Juniper. Data dianalisis menggunakan uji Wilcoxon dan Mann Whitney.

Hasil: Dari 34 subjek terbagi dalam dua kelompok, perbaikan skor TNSS, skor nasoendoskopi, dan skor RQLQ didapatkan hasil yang signifikan $(\mathrm{p}<0,05)$ pada tiap kelompok pascaterapi. Namun perbandingan seluruh variabel pemeriksaan pasca terapi antara kedua kelompok tidak siginifikan $(\mathrm{p}>0,05)$.

Simpulan: Pemberian kapsul ekstrak kulit manggis sebagai terapi adjuvan tidak efektif pada pasien RA menetap derajat sedang berat dalam meningkatkan efektivitas terapi standar.

Kata kunci: ekstrak kulit manggis, klinis, terapi adjuvan, rinitis alergi. 
Abstract

Background: Allergic rhinitis (RA) is an inflammatory disease in the IgE-mediated nasal mucosa after allergen exposure. Pollution can aggravate allergic inflammation. RA therapy is aimed at improving symptoms, preventing deterioration, and improving quality of life. Mangosteen skin extract is an herb commonly used as adjuvant / additional therapy with anti-inflammatory and antioxidant effects. Antioxidant capacity is higher than other fruit. The purpose of this study was to assess the improvement of clinical symptoms, clinical signs, and quality of life in moderate to severe RA.

Methods: This research is a quasi experimental randomized trial of open label pre and post test design. The research took place in the polyclinic of Ear Nose Throat Surgery Head Surgery of Neck Hospital. Hasan Sadikin Bandung in September-November 2013. The control group received standard therapy in the form of loratadine tablet and intranasal corticosteroid, while the treatment group was given additional mangosteen leaf extract capsule for 14 days. Diagnosis based on anamnesis, physical examination and puncture skin test. Then assessed the semiticivity of Weeke, Davis and Okuda (TNSS) nose score, Lund Kennedy's adaptation nasoendoskopi score, and Juniper's RQLQ quality-disruption score. Data were analyzed using the Wilcoxon and Mann Whitney tests.

Results: Of 34 subjects divided into two groups, improvement of TNSS score, nasoendoskopi score, and RQLQ score showed significant results $(\mathrm{p}<0.05)$ in each post-therapy group. However, the comparison of all post-therapy examination variables between the two groups was not significant ( $>>0.05$ ).

Conclusion: The administration of mangosteen skin extract capsules as adjuvant therapy is not effective in patients with moderate to severe RA in improving the effectiveness of standard therapy.

Keywords: mangosteen skin extract, clinical, adjuvant therapy, allergic rhinitis.

\section{PENDAHULUAN}

Rinitis alergi (RA) adalah suatu proses inflamasi pada mukosa hidung yang diperantarai oleh IgE setelah pajanan alergen. Gejalanya terdiri dari hidung beringus, hidung tersumbat, hidung gatal dan bersin yang dapat membaik secara spontan atau melalui pengobatan. Penyakit ini bersifat multifaktorial yang diinduksi oleh interaksi antara faktor genetik dan lingkungan termasuk polutan. RA diklasifikasikan menjadi ringan dan sedang-berat, serta sewaktu-waktu dan menetap. ${ }^{1}$

Prevalensi rinitis alergi terus meningkat, diperkirakan mengenai lebih dari 500 juta penduduk di seluruh dunia atau sekitar 10-40\%. Di Asia Pasifik sendiri tercatat terdapat lebih dari 150 juta penduduk menderita rinitis alergi. RA dapat mengganggu kualitas hidup pasien. ${ }^{1}$ Biaya pengobatannya pun sangat besar, karena terdapat biaya langsung mencapai 1,16 hingga 4,5 milyar US dolar maupun biaya tidak langsung berupa 3,5 juta hari tidak masuk kerja dan 2 juta hari tidak sekolah setiap tahunnya. ${ }^{2}$

Secara patogenesis, inflamasi pada rinitis alergi diawali dengan fase sensitisasi, reaksi alergi fase cepat (RAFC) dan reaksi alergi fase lambat (RAFL). Pada RAFC terjadi degranulasi sel mast sehingga dihasilkan sejumlah mediator seperti histamin, prostaglandin dan lekotrin.
Pada RAFL terjadi infiltrasi sejumlah sel inflamasi seperti eosinofil akibat molekul ICAM1 (Intercellular adhesion molecule 1). Kemudian dihasilkan sejumlah sitokin inflamasi seperti interleukin (IL) IL-4, IL-6, TNF- $\alpha$ dan lainnya. ${ }^{3}$

Adapun jalur pembentukan sitokin dan molekul inflamasi adalah melalui transkripsi gen sitokin oleh NFkB (Nuclear factor kappa B) pada inti sel. Dan Aktivator NFkB diantaranya adalah radikal bebas oksidan yaitu ROS (Reactive oxygen species) seperti polusi udara. ${ }^{4}$ Zhao $\mathrm{dkk}^{5}$ (2008) mendapatkan terjadi peningkatan ekspresi NFkB dan mRNA ICAM-1 pada mukosa hidung pasien rinitis alergi.

ROS yang berasal dari polusi kendaraan bermotor dapat memperkuat inflamasi alergi dengan meningkatkan produksi IgE melalui stimulasi sel $\mathrm{B}$, memperkuat produksi $\operatorname{IgE}$ spesifik terinduksi alergen, menstimulasi produksi sitokin IL-4 dan IL-6, merangsang Th2, menginduksi influks sel inflamasi dengan meningkatkan ekspresi ICAM-1, memperkuat produksi kemokin, menginduksi $\mathrm{NFkB}$ dalam mengekspresi IL-8, IL-6 serta TNF- $\alpha .{ }^{6}$ Hwang $\mathrm{dkk}^{7}$ (2006) menyimpulkan bahwa paparan polutan $\mathrm{NOx}, \mathrm{CO}$ dan $\mathrm{SO}_{2}$ akan meningkatkan kejadian rinitis alergi. Kemudian Sequeira $\mathrm{dkk}^{8}$ (2012) bahwa terdapat peran stres oksidatif dalam rinitis alergi menetap derajat sedang berat 
sehingga strategi menjaga keseimbangan ROS dan kapasitas antioksidan total dapat bermanfaat dalam rinitis alergi.

Dalam kaitan ini, kulit buah manggis (Garcinia mangostana Linn, GML) telah lama digunakan dalam pengobatan. Penelitian menunjukkan ekstrak kulit manggis (EKM) yang mengandung zat aktif ksanton memiliki aktivitas antioksidan dan antiinflmasi. ${ }^{9}$ Khususnya sebagai antioksidan, EKM memiliki kapasitas dalam menangkal radikal oksigen sekitar 10.000 kali lipat makanan alami lain. ${ }^{10}$ Dalam perannya tersebut, maka EKM dapat diasumsikan mampu lebih meningkatkan efektivitas terapi standar yang dianut saat ini.

Penatalaksanaan medikamentosa standar rintis alergi menetap derajat sedang berat berdasarkan ARIA-WHO adalah antihistamin oral dan steroid intranasal. Selain itu ARIAWHO 2008 juga mencatat bahwa pengobatan CAM (Complementary Alternative Medicine) dalam terapi rinitis alergi dan asma seperti herbal secara praktis, telah banyak digunakan dan pasien merasa puas. Meskipun pengobatan ini masih tergolong tingkat $\mathrm{D}$ (low level of evidence). ${ }^{1}$

ARIA-WHO tahun 2010 memberikan rekomendasi bersyarat (lemah) dengan tingkat kualitas bukti yang masih sangat rendah untuk tidak menggunakan obat herbal dalam pengobatan rinitis alergi. ${ }^{11}$ Namun dengan meluasnya penggunaan CAM pada pengobatan rinitis alergi di seluruh dunia serta meningkatnya prevalensi penyakit alergi, maka penting bagi dokter THT-KL untuk lebih memahami pemanfaatannya. ${ }^{12}$ Oleh karena itu dibutuhkan lebih banyak penelitian tambahan untuk sebuah rekomendasi pengobatan herbal pada rinitis alergi.

Berdasarkan uraian di atas, peneliti tertarik untuk melakukan penelitian prospektif di poliklinik alergi THT-KL RS Hasan Sadikin
Bandung guna melihat manfaat EKM pada pasien rinitis alergi dengan menilai gejala dan tanda klinis, serta kualitas hidup, juga mencatat efek sampingnya apabila ditemukan.

\section{METODE PENELITIAN}

Subjek penelitian ini adalah pasien rinitis alergi menetap derajat sedang berat berusia 1849 tahun yang menandatangani informed consent, serta bersedia datang 14 hari pasca terapi dan diasumsikan bekerja/sekolah.berdomisili di kawasan kota Bandung dengan tingkat polusi udara tinggi (menurut pemetaan Badan Pengendalian Lingkungan Hidup $)^{13}$.

Penelitian ini merupakan quasi experimental randomized trial open label pre and post test design dengan 2 kelompok perlakuan. Pertama kelompok kontrol yang mendapatkan terapi standar berupa steroid semprot hidung triamsinolon asetonid 1 x 2 semprot (220 $\mathrm{mcg} /$ hari) dan tablet loratadin 1 x $10 \mathrm{mg} /$ hari. Kedua kelompok perlakuan yang mendapatkan terapi standar dan terapi adjuvan kapsul EKM $2 \times 550 \mathrm{mg}$. Adapun variabel yang diukur pra dan pasca terapi adalah skor gejala hidung (semikuantitatif Weeke,Davis dan Okuda) ${ }^{14}$, skor endoskopi hidung (adaptasi Lund-Kennedy) ${ }^{15}$, dan skor gangguan kualitas hidup (RQLQ dari Juniper). ${ }^{16}$

Analisis data untuk membandingkan variabel ukur kedua kelompok pasca terapi menggunakan uji Mann Whitney. Kemaknaan hasil uji dikatakan bermakna jika $p<0,05$ dan dianalisis secara statistik.

Penelitian ini akan dilakukan di poliklinik Rino-Alergi THT-KL RS. Dr. Hasan Sadikin. Waktu penelitian dimulai dari penelitian ini disetujui oleh Komite Etik dan Penelitian RSHS (No: $\quad$ LB.04.01/A05/EC/084/IX/2013) September hingga Nopember 2013. 


\section{HASIL DAN PEMBAHASAN}

Tabel 1 Karakteristik Jenis Kelamin dan Usia Subjek pada Kedua Kelompok Penelitian

\begin{tabular}{|c|c|c|c|}
\hline \multirow[t]{2}{*}{ Karakteristik } & \multicolumn{2}{|c|}{ Kelompok penelitian } & \multirow[t]{2}{*}{ Nilai p } \\
\hline & $\begin{array}{l}\text { Kelompok } \\
\text { Perlakuan }\end{array}$ & Kelompok Kontrol & \\
\hline Jenis kelamin & & & $\left.0,724^{*}\right)$ \\
\hline Laki-laki & 6 & 7 & \\
\hline Perempuan & 11 & 10 & \\
\hline Usia (tahun) & & & $\left.0,454^{* *}\right)$ \\
\hline$<20$ & - & 1 & \\
\hline $20-29$ & 10 & 10 & \\
\hline $30-39$ & 4 & 5 & \\
\hline $40-49$ & 3 & 1 & \\
\hline Rerata (SD) & $29,8(8,9)$ & $27,2(6,3)$ & \\
\hline Median & 27 & 25 & \\
\hline Rentang & $20-49$ & $19-41$ & \\
\hline
\end{tabular}

Berdasarkan hasil perhitungan analisis statistik pada tabel 1 menunjukkan bahwa jenis kelamin pada kedua kelompok penelitian berdasarkan uji eksak Fisher memiliki nilai $\mathrm{p}=$ 0,724; sehingga kedua jenis kelamin secara statistik tidak berbeda bermakna. Usia subjek penelitian berdasarkan uji Mann Whitney memiliki nilai $\mathrm{p}=0,454 ; \quad$ sehingga tidak didapatkan perbedaan bermakna. Maka dapat disimpulkan bahwa subjek pada kedua kelompok penelitian ini ditinjau dari jenis kelamin dan usia bersifat homogen, sehingga layak untuk diperbandingkan.

Tabel 2 Jumlah Jenis Polutan yang Melebihi Ambang Baku di Area Domisili dan Tempat Bekerja/Sekolah Subjek Penelitian

\begin{tabular}{|c|c|c|c|}
\hline \multirow[b]{2}{*}{ Polutan } & \multicolumn{2}{|c|}{ Kelompok penelitian } & \multirow[t]{2}{*}{ Nilai $p$} \\
\hline & Perlakuan & Kontrol & \\
\hline Area Domisili & & & $\left.0,658^{*}\right)$ \\
\hline - $\quad$ Rerata (SD) & $2,8(0,7)$ & $2,7(0.8)$ & \\
\hline - Median & 3 & 3 & \\
\hline - Rentang & $2-4$ & $2-4$ & \\
\hline Area Bekerja/Sekolah & & & $\left.0,586^{*}\right)$ \\
\hline - $\quad$ Rerata (SD) & $2,1(0,4)$ & $2,2(0,5)$ & \\
\hline - Median & 2 & 2 & \\
\hline - Rentang & $2-4$ & $2-4$ & \\
\hline
\end{tabular}

Keterangan: $*$ ) berdasarkan uji Mann-Whitney.

$\mathrm{SD}=$ Standar deviasi; Bermakna bila $\mathrm{p}<0,05$

Pada tabel 2, melalui uji Mann Whitney, didapatkan tidak terdapat perbedaan bermakna pada jumlah polutan yang melewati ambang baku di area domisili $(p=0,658)$ dan jumlah polutan yang melewati ambang baku di area sekolah/bekerja $(\mathrm{p}=0,586)$ diantara kedua kelompok. 
Tabel 3 Perbandingan Hasil Tes Kulit Tusuk pada Kelompok Penelitian

\begin{tabular}{lccc}
\hline \multirow{2}{*}{ Ekstrak alergen } & \multicolumn{2}{c}{ Kelompok penelitian } & \\
\cline { 2 - 3 } & Perlakuan $\mathbf{( n = 1 7 )}$ & $\begin{array}{c}\text { Kontrol } \\
(\mathbf{n}=\mathbf{1 7})\end{array}$ & Nilai $\mathbf{p}^{*}$ \\
\hline Dermatophagoides pteronyssinus & 16 & 17 & 1,0 \\
Dermatophagoides farinei & 9 & 9 & 1,0 \\
Cat fur & 4 & 3 & 0,8 \\
Dog Hair & 4 & 2 & 0,6 \\
Cockroach & 6 & 7 & 0,8 \\
Aspergillus sp & 3 & 2 & 0,8 \\
\hline Keterangan : ${ }^{*}$ berdasarkan uji eksak Fisher. Bermakna jika nilai $\mathrm{p}<0,05$. & &
\end{tabular}

Pada penelitian ini tidak ada perbedaan signifikan alergen inhalan pencetus alergi antara kelompok perlakuan dengan kelompok kontrol. Berdasarkan perhitungan statistik pada tabel 3, dengan menggunakan uji Eksak Fisher pada tujuh alergen inhalan, masing-masing didapatkan $\mathrm{p}>0,05$. Hal ini menunjukkan hasil tes alergi kedua kelompok bersifat homogen.

Tabel 4 Perbandingan Variabel Ukur Pra Terapi Kedua Kelompok Penelitian

\begin{tabular}{|c|c|c|c|}
\hline \multirow{2}{*}{$\begin{array}{l}\text { Variabel } \\
\text { Ukur }\end{array}$} & \multicolumn{2}{|c|}{ Kelompok penelitian } & \multirow{2}{*}{ Nilai $p$} \\
\hline & $\begin{array}{l}\text { Kelompok } \\
\text { Perlakuan }\end{array}$ & Kelompok Kontrol & \\
\hline \multicolumn{4}{|l|}{ TNSS } \\
\hline \multicolumn{4}{|l|}{ (Median) } \\
\hline Hidung Tersumbat & 2 & 2 & 0,62 \\
\hline Hidung Beringus & 2 & 2 & 0,62 \\
\hline Bersin Bersin & 3 & 3 & 0,433 \\
\hline Hidung Gatal & 2 & 2 & 1 \\
\hline TSGH & 9 & 9 & 0,708 \\
\hline \multicolumn{4}{|l|}{$\begin{array}{l}\text { Nasoendoskopi } \\
\text { (Median) }\end{array}$} \\
\hline Edema Mukosa & 2 & 2 & 0,563 \\
\hline Sekret Kavum Nasi & 2 & 2 & 0,150 \\
\hline \multirow{2}{*}{\multicolumn{4}{|c|}{$\begin{array}{l}\text { RQLQ } \\
\text { (Median) }\end{array}$}} \\
\hline & & & \\
\hline Activities & 10 & 9 & 0,306 \\
\hline Sleep & 7 & 6 & 0,114 \\
\hline Non-Nose/Eye Symp. & 9 & 8 & 0,150 \\
\hline Practical Problems & 7 & 6 & 0,760 \\
\hline Nasal Symp. & 9 & 10 & 0,1000 \\
\hline Eye Symp. & 4 & 2 & 0,99 \\
\hline Emotional & 3 & 3 & 0,760 \\
\hline
\end{tabular}

Pada tabel 4 variabel-variabel ukur pra terapi kedua kelompok pada penelitian ini tidak menunjukkan perbedaan yang bermakna. Sehingga variabel TNSS, skor endoskopi, dan
RQLQ pemeriksaan subjek kedua kelompok bersifat homogen dan layak untuk diperbandingkan. 
Tabel 5 Perbandingan Variabel Ukur Pasca Terapi Kedua Kelompok Penelitian

\begin{tabular}{|c|c|c|c|}
\hline \multirow{2}{*}{$\begin{array}{l}\text { Variabel } \\
\text { Ukur }\end{array}$} & \multicolumn{2}{|c|}{ Kelompok penelitian } & \multirow[t]{2}{*}{ Nilai $p$} \\
\hline & $\begin{array}{l}\text { Kelompok } \\
\text { Perlakuan }\end{array}$ & Kelompok Kontrol & \\
\hline \multirow{2}{*}{\multicolumn{4}{|c|}{$\begin{array}{l}\text { TNSS } \\
\text { (Median) }\end{array}$}} \\
\hline & & & \\
\hline Hidung Tersumbat & 1 & 1 & 0,433 \\
\hline Hidung Beringus & 1 & 1 & 0,245 \\
\hline Bersin Bersin & 1 & 1 & 0,231 \\
\hline Hidung Gatal & 1 & 1 & 0,586 \\
\hline TSGH & 4 & 4 & 0,433 \\
\hline \multicolumn{4}{|l|}{$\begin{array}{l}\text { Nasoendoskopi } \\
\text { (Median) }\end{array}$} \\
\hline Edema Mukosa & 0 & 0 & 0,786 \\
\hline Sekret Kavum Nasi & 0 & 0 & 0,245 \\
\hline \multirow{2}{*}{\multicolumn{4}{|c|}{$\begin{array}{l}\text { RQLQ } \\
\text { (Median) }\end{array}$}} \\
\hline & & & \\
\hline Activities & 4 & 4 & 0,892 \\
\hline Sleep & 3 & 3 & 0,150 \\
\hline Non-Nose/Eye Symp. & 4 & 4 & 0,245 \\
\hline Practical Problems & 3 & 4 & 0,518 \\
\hline Nasal Symp. & 5 & 5 & 0,734 \\
\hline Eye Symp. & 2 & 1 & 0,205 \\
\hline Emotional & 0 & 1 & 0,892 \\
\hline
\end{tabular}

Keterangan : TNSS (Total Nasal Symptom Score), RQLQ (Rbinoconjungtivitis Quality of Life Questionaire), Symp:Symptoms TSGH (Total Skor Gejala Hidung). Bermakna jika nilai p $<0,05$.

Berdasarkan uji Mann Whitney pada tabel 5 variabel-variabel ukur pasca terapi kedua kelompok pada penelitian ini tidak menunjukkan nilai $\mathrm{p}>0,05$. Sehingga perbaikan gejala dan tanda klinis serta peningkatan kualitas hidup kelompok pasien rinitis alergi menetap derajat sedang berat yang hanya mendapatkan terapi standar dibandingkan dengan kelompok pasien yang mendapatkan terapi standar dan adjuvan EKM tidak terdapat perbedaan bermakna.

Jenis kelamin perempuan lebih banyak dibandingkan dengan laki-laki 1,6:1, Hal ini sesuai dengan survey rinitis alergi di Amerika Serikat tahun 2007. ${ }^{17}$ Dengan usia terbanyak pada kelompok 20-39, yang sesuai dengan penelitian Arifianto $\mathrm{dkk}^{18}$, dimana rinitis alergi terbanyak pada kelompok usia produktif antara 20 - 30 tahunan, Hasil tes kulit tusuk didapatkan alergen spesifik positif pada subjek seri penelitian ini yang terbanyak adalah Dermatophagoides pteronyssinus (Der $\mathrm{p}$ ) sebanyak 33 subjek $(97 \%)$. Hal ini sesuai dengan penelitian Arifianto $\mathrm{dkk}^{18}$ dimana hasil tes kulit tusuk positif terbanyak adalah tungau Der p $(82,8 \%)$.

Pada penelitian ini digunakan loratadin sebagai antagonis reseptor $\mathrm{H} 1$, dimana reseptor ini terdapat pada organ efektor sehingga gejala bersin-bersin, gatal hidung serta hidung beringus dapat berkurang atau menghilang. Akan tetapi manfaat terhadap hidung tersumbat umumnya berefek minimal. ${ }^{19}$ Pada penelitian ini juga digunakan kortikosteroid semprot hidung triamsinolon asetonid dengan potensi inhibisi $\mathrm{IC}_{50}$ terhadap IL-4 sebesar 11,1 nmol/L, IL-5 9,8 $\mathrm{nmol} / \mathrm{L}$, proliferasi sel $\mathrm{T}$ sebesar 1,0 $\mathrm{nmol} / \mathrm{L}$, pelepasan histamin basofil sebesar 20,0 $\mathrm{nmol} / \mathrm{L}$ dan apoptosis eosinofil sebesar 23,8 $\mathrm{nmol} / \mathrm{L} .{ }^{20}$ Penggunaan obat-obatan antihistamin oral serta kortikosteroid semprot hidung sebagai antiinflamasi bertujuan untuk menghambat mediator-mediator dan sitokin inflamasi alergi yang berdampak pada organ target.29-32 Sehingga sekret kavum nasi berkurang dan konka inferior tidak edema atau hipertrofi.

Begitupula pemberian terapi tambahan EKM sebagai antioksidan dan antiinflamasi diharapkan akan lebih memperbaiki tanda dan gejala klinis serta kualitas hidup pasien rinitis alergi. Khusus terkait rinitis alergi, penelitian Nakatani dkk (2004), mendapatkan ksanton $\gamma$ mangostin dapat menghambat aktivasi NFkB sehingga mencegah terbentuknya prostaglandin yang ditandai dengan hilangnya edema pada cakar hewan coba tikus. ${ }^{21}$ Penelitian lainnya oleh Chae dkk (2012), dikatakan bahwa ksanton $\alpha$ dan $\gamma$ mangostin 
dapat menghambat pelepasan mediator alergi (IL-6, Prostaglandin D2 dan lekotrin C4) dari sel mast pada media sumsum tulang. ${ }^{22}$ Begitupula Liu dkk (2012), mendapatkan $\alpha$ mangostin in vitro memiliki efek antiinflamasi dengan menghambat pembentukan IL-4 dan TNF- $\alpha$ pada kultur sel U937.23

Akan tetapi observasi gejala klinis, tanda klinis dan perbaikan kualitas hidup pasca terapi dalam penelitian ini tidak berbeda bermakna antara kelompok yang mendapatkan terapi adjuvan kapsul EKM dibandingkan dengan kelompok yang hanya mendapatkan terapi standar. Hal ini mungkin disebabkan waktu pemberian yang kurang lama, dosis terapi EKM yang kurang efektif atau kemampuan terapi EKM tersamar oleh potensi kortikosteroid. Simpulan ekstrak kulit manggis sebagai bagian dari pengobatan adjuvan tidak efektif pada pasien rinitis alergi menetap derajat sedang berat dalam meningkatkan efektivitas terapi standar.

\section{SIMPULAN}

Pemberian kapsul ekstrak kulit manggis sebagai terapi adjuvan tidak efektif pada pasien RA menetap derajat sedang berat dalam meningkatkan efektivitas terapi standar.

\section{DAFTAR PUSTAKA}

1. Bousquet J, Khaltaev N, Cruz AA, Denburg J, Fokkens WJ, Togias A, et al. Allergic Rhinitis and its Impact on Asthma (ARIA) 2008 update (in collaboration with the World Health Organization, GA(2)LEN and AllerGen). Allergy. 2008;63:86:1-135.

2. Nathan RA. The burden of allergic rhinitis. Allergy Asthma Proc. 2007;28:1:3-9.

3. Sin B, Togias A. Pathophysiology of Allergic and Nonallergic Rhinitis. Proc Am Thorac Soc. 2011;8:106-114.

4. Oeckinghaus A, Ghosh S. The NFkB Family of Transcription Factor and Its Regulation. Cold Spring Harb Perspect Biol. 2009;1:1-14.

5. Zhao J, Wang Y, Kong W. Expression and significance of nuclear factorkappaB and ICAM-1 mRNA in nasal mucosa of allergic rhinitis. Lin Chung Er Bi Yan Hou Jing Wai Ke Za Zhi (Article in Chinese). 2008.;22(2):57-60.

6. Riedl M, Sanchez DD. Biology of diesel exhaust effects on respiratory function. J Allergy Clin Immunol. 2005;115:221-8.
7. Hwang BF, Jaakkola JJK, Lee YL, Lin YC, Guo YL. Relation between air pollution and allergic rhinitis in Taiwanese schoolchildren. Respiratory Research. 2006;7;23:1-7.

8. Sequeira S, Rao AV, Rao A. Increased oxidative stress and altered antioxidants status in patients with chronic allergic rhinitis. Advances in Bioscience and Biotechnology. 2012;3:951-956.

9. Chaverri JP, Rodriguez NC, Ibarra MO, Jazmin, Rojas P. Medicinal properties of mangostreen (Garcinia mangostana). Food and Chemical Toxicology. 2008;48:3227-3239.

10. Paramawati R. Dahsyatnya Manggis untuk Menumpas Penyakit. Cet.1. Jakarta Selatan:PT AgroMedia Pustaka. 2010. h. 47-57.

11. Brozek JL, Bousquet J, Cagnani CEB, Bonini S, Canonica GW, Casale TB, et al. Allergic Rhinitis and its Impact on Asthma (ARIA) guidelines: 2010 Revision. J Allergy Clin Immunol. 2010;126:466-76.

12. Man LX. Complementary and alternative medicine for allergic rhinitis. Curr Opin Otolaryngol Head Neck Surg. 2009;17:226-231.

13. Urban Air Quality Improvemnet Project (UAQ-i). Atlas Kualitas Udara Kota Bandung. Jakarta:BAPPENAS;2006.

14. Weeke B, Davies RJ, Okuda M. Allergy diagnosis in vivo. Dalam: Mygind $\mathrm{N}$, Weeke B, editor. Allergic and vasomotor rhinitis: clinical aspect. Edisi 1. Copenhagen:Munksgaard.1986. h.40.

15. Lund VJ, Kennedy DW. Staging for rhinosinusitis. Otolaryngol Head Neck Surg. 1997;117:S35-S40.

16. Juniper EF, Thompson AK, Ferrie PJ, Robert JN. Validation of the standardized version of the Rhinoconjugntivitis Quality of Life Questionnaire. J Allergy Clin Immunol. 1999;104:364-9.

17. Schatz M. A survey of the burden of allergic rhinitis in the USA. Allergy. 2007:62(S85):9-16.

18. Arifianto A, Madiadipoera $T$, Dermawan A, Sudiro M. Karakteristik rinitis alergi di poliklinik ilmu kesehatan THT-KL RS Dr. Hasan Sadikin. 9th Jakarta International Functional Endoscopy Sinus Surgery; 24 Februari 2013. Jakarta, Indonesia. h. 1-11 
19. Greiner AN, Meltzer EO. Pharmacologic rationale for treating allergic and nonallergic rhinitis. J Allergy Clin Immunol. 2006;118:985-96.

20. Mygind N, Nielsen LP, Hoffmann H, Shukia A, Blumberga G, Dahl R, Jacobi H. Mode of action of intranasal corticosteroids. J Allergy Clin Immunol. 2001;108:S16-25

21. Nakatani I, Yamakuni N, Kondo N, Arakawa T, Oosawa K, Shimura S, et all. gamma-Mangostin inhibits inhibitorkappaB kinase activity and decreases lipopolysaccharide-induced cyclooxygenase-2 gene expression in C6 rat glioma cells. Mol Pharmacol. 2004;66;(3):667-74.

22. Chae HS, Oh SR, Lee HK, Joo SH, Chin YW. Mangosteen xanthones, $\alpha$ and $\gamma$-mangostins, inhibit allergic mediators in bone marrow-derived mast cell. Food Chemistry. 2012;134;1:397400.

23. Liu SH, Lee LT, Hu NY, Huange KK, Shih YC, Munekazu L, et al. Effect of alpha-mangostin on the expression of anti-inflammatory genes in U937 cells. Chinese Medicine. 2012;7;19:1-1. 